\title{
Arbuscular mycorrhizal and dark septate fungal associations in shallot (Allium cepa L. var. aggregatum) under conventional agriculture
}

\author{
Perumalsamy Priyadharsini ${ }^{1}$, Radha Raman PANDEy ${ }^{2}$, \\ THANGAVElu MUTHUKUMAR ${ }^{1 *}$ \\ ${ }^{1}$ Root and Soil Biology Laboratory, Department of Botany, Bharathiar University, \\ Coimbatore 641 046, Tamilnadu, India. \\ ${ }^{2}$ Department of Life Sciences, Manipur University, Canchipur, Imphal 795 003, India
}

\begin{abstract}
We examined roots of the shallot (Allium cepa L. var. aggregatum), one of the most popular cultivated crops of the family Aliaceae, cultivated under conventional agriculture for arbuscular mycorrhizal fungal (AMF) and dark septate fungal endophyte (DSE) associations. All the plants had dual colonization of both AMF and DSE associations. The intermediate-type AMF morphology in the shallot is the first report of this AMF type for the family Aliaceae. The extents of total AMF and DSE colonization ranged from 20.7 to $67.3 \%$ and 3.6 to $35.3 \%$ respectively and varied significantly among fields. Though no significant relationship existed between total AMF and DSE variables, they were correlated to the soil variables. Significant correlations existed between soil P and microscelerotia and also between soils $\mathrm{N}$ and $\mathrm{K}$ and AMF spore numbers. A total of six AMF spore morphotype belonging to Glomus and Scutellospora were identified. Scutellospora calospora was the most dominant morphotype in the studied fields.
\end{abstract}

Keywords: Allium, arbuscular, endophyte, mycorrhiza, Glomus, Scutellospora

Abbreviations: AMF - arbuscular mycorrhizal fungus, DSE - dark-septate endophyte

\section{Introduction}

The herbaceous biennial Allium cepa L. (onion) is the most widely cultivated taxon in the family Alliaceae. The onion A. cepa var. aggregatum is native to South West Asia, but cultivated worldwide. Crops benefit from arbuscular mycorrhizal fungus (AMF) through enhanced uptake of nutrients with low mobility, especially phosphorus. The non-nutritional benefits of AMF include alleviation of plant stresses caused by biotic and abiotic fac-

\footnotetext{
* Corresponding author, e-mail: tmkum@yahoo.com

Copyright ${ }^{\circledR} 2012$ by Acta Botanica Croatica, the Faculty of Science, University of Zagreb. All rights reserved.
} 
tors, and the stabilizing of soil aggregates (SMITH and READ 2008, BolANDNAZAR et al. 2007, JAIME et al. 2008, GiANINAZZI et al. 2010).

The onion has an inefficient, mostly unbranched, shallow root system with sparse root hairs, and cannot maintain adequate uptake of nutrients such as phosphorus $(\mathrm{P})$ that diffuse slowly through the soil solution, which has a negative effect on yields (MENGEL and KIRKBY 2001). Onions are highly mycorrhizal-dependent (DERESSA and SCHENK 2008). Previous studies do indicate that the onion is highly responsive to mycorrhization, resulting in improved plant growth and yield under normal as well as stressed conditions (JAIME et al. 2008, Bolandnazar et al. 2007, Goussous and MoHAmmad 2009, GALVÁn et al. 2011). A significant correlation between natural AMF colonization and onion yields in conventionally managed onion farmlands has recently been reported (GALVÁN et al. 2009). In conventional agriculture, large amounts of fertilizers are used to increase the yield of onion (BOSCH-SERRA and CURRAH 2002). Additionally large amounts of biocides are used in shallot cultivation as this plant is very susceptible to pests and diseases (ANONYMOUS 1986, SUHARDI 1996). Large scale use of fertilizers, biocides and tillage affect both arbuscular mycorrhizal formation and function (see PLENCHETTE et al. 2005).

Diversity of AMF species seems to be essential for sustainable functioning of the ecosystem in the event of sudden changes in environmental conditions (WANG et al. 1985, ABBOTT and GAZEY 1994). Studies indicate the existence of variation in life histories, reproduction abilities and morphology among AMF species (DICKSON 2004, HART et al. 2001, HART and READER 2002). Agricultural practices may induce selection pressure in such a way that a certain AMF group could adapt to changes, establish and proliferate better than others (SINGH et al. 2008). For example, SINGH et al. (2008) indicated that Camellia sinensis growing under natural conditions harboured a greater diversity of AMF species than those under cultivation. Further the composition of AMF community could be strongly influenced by the individual plant species through differential effects on mycorrhizal establishment and sporulation (SANDERS and FITTER 1992, BEVER et al. 1996). It is becoming increasingly important to gain a better understanding of AMF diversities under field conditions, as suggested by HUSBAND et al. (2002). Limited studies have examined AMF diversities associated with specific plant species like Vitis vinifera (BALESTRINI et al. 2010), Solanum tuberosum (DAS and KAYANG 2010b), Michelia champaca (DAS and KAYANg 2010a), Phaseolus aureus (VALSALAKUMAR et al. 2007) and Camellia sinensis (SINGH et al. 2008). Recently, GALVÁn et al. (2009) reported AMF polytypes in onion roots under organic and conventional farming systems using rDNA sequencing.

Crop roots are also colonized by a diverse group of melanaceous, septate fungi known as dark septate fungal endophytes (DSE). The function of DSE in plant roots is unclear and may range from pathogenic or saprophytic to mutualistic (JUMPPONEN and TRAPPE 1998, JUMPPONEN 2001). The occurrence of DSE on several temperate and tropical crop species has been reported (Jumpronen and Trappe 1998, Muthukumar and TAmilselvi 2010). ADDY et al. (2005) speculated that the nature of DSE association with roots may be broader than nutrient transfer as there is no evidence of any specific fungal requirements from the host. An analysis of the role of DSE in ecosystems (MANDYAM and JUMPPONEN 2005) indicated facilitation of nutrient uptake of the host plant, alterations in host water uptake, stress tolerance and utilization of wider nutrient pools by the host through DSE. MANDYAM and 
JUMPPONEN (2008) also suggested that a knowledge of DSE abundance in relation to root-associated fungi is essential to understand this significance.

In this study, we examined root colonization by AMF and DSE in shallots under conventional agriculture. The three main questions addressed in this study were (i) Does AMF and DSE colonization vary within and between cultivated fields? (ii) Is there any relationship between AMF and DSE within roots? (iii) Do soil factors influence AMF and DSE colonization or structures within roots? In addition we also assessed the AMF spore numbers to see if they were related to colonization levels and assessed their diversity with the shallot.

\section{Materials and methods}

\section{Sampling}

Onion root and soil samples were collected during December 2009 from 20 different onion fields (hereafter referred to as F1 to F20) from Sathyamangalam $\left(11^{\circ} 28^{\prime} \mathrm{N}\right.$ and $77^{\circ} 59^{\prime} \mathrm{E}, 540 \mathrm{~m}$ a.s.1), Tamil Nadu, Southern India. The average annual rainfall of this area is $360-600 \mathrm{~mm}$. All the fields selected had uniform cultivation practices and cultivation periods (November to January). The fields were canal-irrigated. Fertilization began with the application of diammonium phosphate (DAP, 16-18\% N, 40-48\% P) during tillage. Fertilizers were further sequentially applied at 25 days (urea- $46 \% \mathrm{~N}$ and DAP), 50 days (ammonium sulphate- $21 \% \mathrm{~N}, 24 \% \mathrm{~S}$ ) and 60 days (muriate of potash) after planting. The crop duration was 70-75 days.

Five randomly selected plants were sampled from each field resulting in a total of 100 plants. Root samples were collected by uprooting the plants. The roots were gently washed free of soil with water, fixed in formalin-acetic acid-70\% alcohol (5:5:90; v:v:v) and brought to the laboratory for further processing. Soil shaken from roots and next to plants was collected and shade dried. The dried soil was divided into two halves. One half of the air-dried soil collected from individual plants was packed separately in polythene bags and stored at $4{ }^{\circ} \mathrm{C}$ to enumerate and extract AMF spores. The second half of the soil of all the individuals from a field was mixed together to form a composite soil sample. These composite soil samples were used to assess the soil chemistry.

\section{Determination of soil characters}

Soil $\mathrm{pH}$ was determined in 1:1 soil: water (v:v) using a digital $\mathrm{pH}$ meter soon after the soil samples arrived in the laboratory. Soil samples were analyzed for sand, silt and clay fractions by the hydrometer method (BoweLs 1992). The total nitrogen (N) and available $\mathrm{P}$ were determined according to JACKSON (1971) and exchangeable potassium (K) was determined after extraction with ammonium acetate (JACKSON 1971). The iron (Fe), manganese $(\mathrm{Mn})$, zinc $(\mathrm{Zn})$ and copper $(\mathrm{Cu})$ were determined according to DTPA method (LINDSAY and NORVELL 1978).

\section{Preparation of roots for AMF and DSE assessment}

Fixed roots were washed thoroughly in tap water. The roots were cut into $1-\mathrm{cm}$ bits, cleared in $2.5 \% \mathrm{KOH}$ at $90{ }^{\circ} \mathrm{C}$ (KosKE and GEMMA 1989) for $60 \mathrm{~min}$, acidified with $5 \mathrm{~N} \mathrm{HCl}$ 
and stained with tryphan blue $(0.05 \%$ in lactoglycerol) overnight. The stained roots were examined with an Olympus BX 51 compound microscope $(400 \times)$ for AMF and DSE structures. Aseptate inter or intracellular, linear or coiled fungal hyphae accompanied with arbuscules or arbusculate coils were used to designate AMF colonization. Melanized, regularly septate fungal hyphae with microsclerotia or moniliform cells characterized DSE colonization. The percentage of root length colonized by AMF and DSE was estimated according to the magnified intersection method (MCGoniGLE et al. 1990). Classification of AMF morphology of the shallot was as per DicKson (2004).

\section{Enumeration and isolation of AMF spores}

Spores were extracted from $100 \mathrm{~g}$ of soil by modifications of the wet-sieving and decanting techniques. After wet-sieving and decanting, the residues on the sieves (710 and $37 \mu \mathrm{m}$ ) were washed into beakers. The beaker contents were collected over a filter paper, spread on Petri dishes and scanned under a dissection microscope at $40 \times$ magnification. All intact spores (non-collapsed with cytoplasmic content) free from parasitic attack were counted. Sporocarps and spore clusters were considered as one unit. For identification, spores with similar morphology were mounted on slides with polyvinyl alcohol-lactic acid-glycerol (PVLG) or PVLG Melzer's reagent for identification (KosKE and TESSIER 1983). Spores were identified based on spore morphology and sub-cellular characters (SCHENCK and PEREZ 1990) using descriptions available on Schüsslers web site (http://www.lrz.de/ schuessler/ amphylo/amphylogeny.html), and INVAM (http://www.invam.caf.wvu.edu).

Frequency of occurrence (\%) for each AMF spore morphotype was calculated as the percentage of the number of the field soil possessing spores of that morphotype. AMF species richness represents the number of taxa occurring in a field.

\section{Statistical analysis}

Data on AMF and DSE colonization and AMF spore numbers were subjected to analysis of variance (ANOVA) to assess the significance of variance among the plants and fields. Pearson's correlation was used to assess the relationship between the root colonization, spore numbers and the soil parameters (SPSS, Windows version 9). Spore numbers were $\log$ transformed and the percentage data on root colonization was arcsine transformed prior to analysis.

\section{Results}

\section{Soil characteristics}

Seventy percent of the fields studied had sandy loam soil with $30 \%$ of the remaining fields having sandy clay loam (Tab. 1). Soil chemistry varied between fields. The soil was moderately basic with the $\mathrm{pH}$ ranging from $7.9(\mathrm{~F} 4-6,9)$ to 8.5 (F19). The EC ranged between 0.18 (F16) and 0.52 (F9) $\mathrm{dS} \mathrm{m}^{-1}$. The total $\mathrm{N}$, available $\mathrm{P}$ and exchangeable $\mathrm{K}$ range observed were 67 (F7, 18) to 118 (F19) $\mathrm{mg} \mathrm{kg}^{-1}, 5$ (F7) to 8 (F17) $\mathrm{mg} \mathrm{kg}^{-1}$ and 200 (F16) to 300 (F19) $\mathrm{mg} \mathrm{kg}^{-1}$ respectively. Similarly, soils had micronutrient concentration ranges of 3.82 (F1, 11) to 7.94 (F19) $\mathrm{mg} \mathrm{kg}^{-1} \mathrm{Fe}, 2.08$ (F1, 11) to 2.99 (F18) $\mathrm{mg} \mathrm{kg}^{-1} \mathrm{Mn}, 1.33$ (F1, 17) to 1.98 (F13) $\mathrm{mg} \mathrm{kg}^{-1} \mathrm{Zn}$ and 0.69 (F16) to 1.66 (F3) $\mathrm{mg} \mathrm{kg}^{-1} \mathrm{Cu}$. 


\begin{tabular}{|c|c|c|c|c|c|c|c|c|c|c|c|c|c|}
\hline \multirow[t]{2}{*}{ Field } & \multirow[t]{2}{*}{ Sand } & \multirow[t]{2}{*}{ Silt } & \multirow[t]{2}{*}{ Clay } & \multirow[t]{2}{*}{ Soil type } & \multirow[t]{2}{*}{$\mathrm{pH}$} & \multirow{2}{*}{$\begin{array}{c}\mathrm{Ec} \\
\left(\mathrm{d} \mathrm{Sm}^{-1}\right)\end{array}$} & $\begin{array}{c}\text { Total } \\
\mathrm{N}\end{array}$ & $\begin{array}{c}\text { Available } \\
\text { P }\end{array}$ & $\begin{array}{c}\text { Exchangeable } \\
\mathrm{K}\end{array}$ & $\mathrm{Fe}$ & $\mathrm{Mn}$ & $\mathrm{Zn}$ & $\mathrm{Cu}$ \\
\hline & & & & & & & \multicolumn{7}{|c|}{$\left(\mathrm{mg} \mathrm{kg}^{-1}\right)$} \\
\hline $\mathrm{F} 1$ & 58 & 13 & 29 & Sandy clay loam & 8.3 & 0.26 & 73 & 5.4 & 225 & 3.82 & 2.08 & 1.33 & 1.41 \\
\hline $\mathrm{F} 2$ & 40 & 16 & 44 & Sandy loam & 8.0 & 0.30 & 76 & 6.4 & 215 & 4.22 & 2.16 & 1.43 & 1.32 \\
\hline F3 & 35 & 30 & 35 & Sandy loam & 8.1 & 0.23 & 78 & 5.2 & 220 & 4.30 & 2.18 & 1.63 & 1.66 \\
\hline F5 & 55 & 23 & 23 & Sandy loam & 7.9 & 0.31 & 76 & 6.8 & 215 & 3.96 & 2.57 & 1.72 & 1.42 \\
\hline F6 & 60 & 16 & 24 & Sandy clay loam & 7.9 & 0.50 & 80 & 7.6 & 205 & 3.90 & 2.52 & 1.59 & 1.37 \\
\hline F7 & 45 & 32 & 23 & Sandy loam & 8.2 & 0.26 & 67 & 5.0 & 205 & 5.12 & 2.47 & 1.63 & 1.40 \\
\hline F8 & 45 & 23 & 32 & Sandy loam & 8.1 & 0.27 & 72 & 5.8 & 220 & 5.69 & 2.52 & 1.78 & 1.52 \\
\hline F9 & 57 & 10 & 33 & Sandy loam & 7.9 & 0.52 & 80 & 6.2 & 225 & 4.42 & 2.62 & 1.72 & 1.52 \\
\hline F13 & 43 & 29 & 29 & Sandy loam & 8.3 & 0.22 & 74 & 5.8 & 220 & 4.17 & 2.64 & 1.98 & 1.43 \\
\hline F14 & 55 & 20 & 25 & Sandy loam & 8.1 & 0.23 & 71 & 7.2 & 235 & 4.20 & 2.64 & 1.55 & 1.27 \\
\hline F15 & 52 & 9 & 39 & Sandy clay loam & 8.2 & 0.33 & 78 & 6.2 & 210 & 3.85 & 2.60 & 1.92 & 1.36 \\
\hline F16 & 36 & 44 & 20 & Sandy loam & 8.1 & 0.18 & 81 & 7.5 & 200 & 4.72 & 2.84 & 1.54 & 0.69 \\
\hline F17 & 46 & 19 & 35 & Sandy clay loam & 8.4 & 0.27 & 84 & 8.0 & 220 & 5.92 & 2.55 & 1.33 & 0.93 \\
\hline $\mathrm{F} 18$ & 76 & 12 & 12 & Sandy loam & 8.2 & 0.38 & 67 & 7.0 & 230 & 6.88 & 2.99 & 1.42 & 0.98 \\
\hline F19 & 53 & 20 & 27 & Sandy clay loam & 8.5 & 0.35 & 118 & 6.0 & 300 & 7.94 & 2.50 & 1.53 & 0.84 \\
\hline F20 & 52 & 19 & 30 & Sandy clay loam & 8.2 & 0.32 & 84 & 7.0 & 235 & 6.16 & 2.74 & 1.40 & 0.79 \\
\hline
\end{tabular}




\section{Determination of AMF and DSE associations}

Roots of all the onion plants examined from different fields had dual colonization of both AMF and DSE. AMF colonization was characterized by the formation of an appressorium on the root surface (Fig. 1a). A colonization peg arising from the appressorium spread within the roots to form intraradical colonization. Colonization is characterized by intracellular hyphae with arbuscules (Fig. 1b), intracellular hyphal coils or arbusculate coils (Fig. 1c), intercellular hyphae and vesicles (Fig. 1d). Arbuscules were present in all the root samples examined. Septate hyphae (Fig. 1e) along with moniliform cells and/or microsclerotia (Fig. 1f) characterized DSE colonization. Microsclerotia was absent in onion roots collected from three fields (F11, F12, F14), whereas moniliform cells were not observed in shallot roots collected from five fields (F1-3, F15, F17) (Tab. 2).

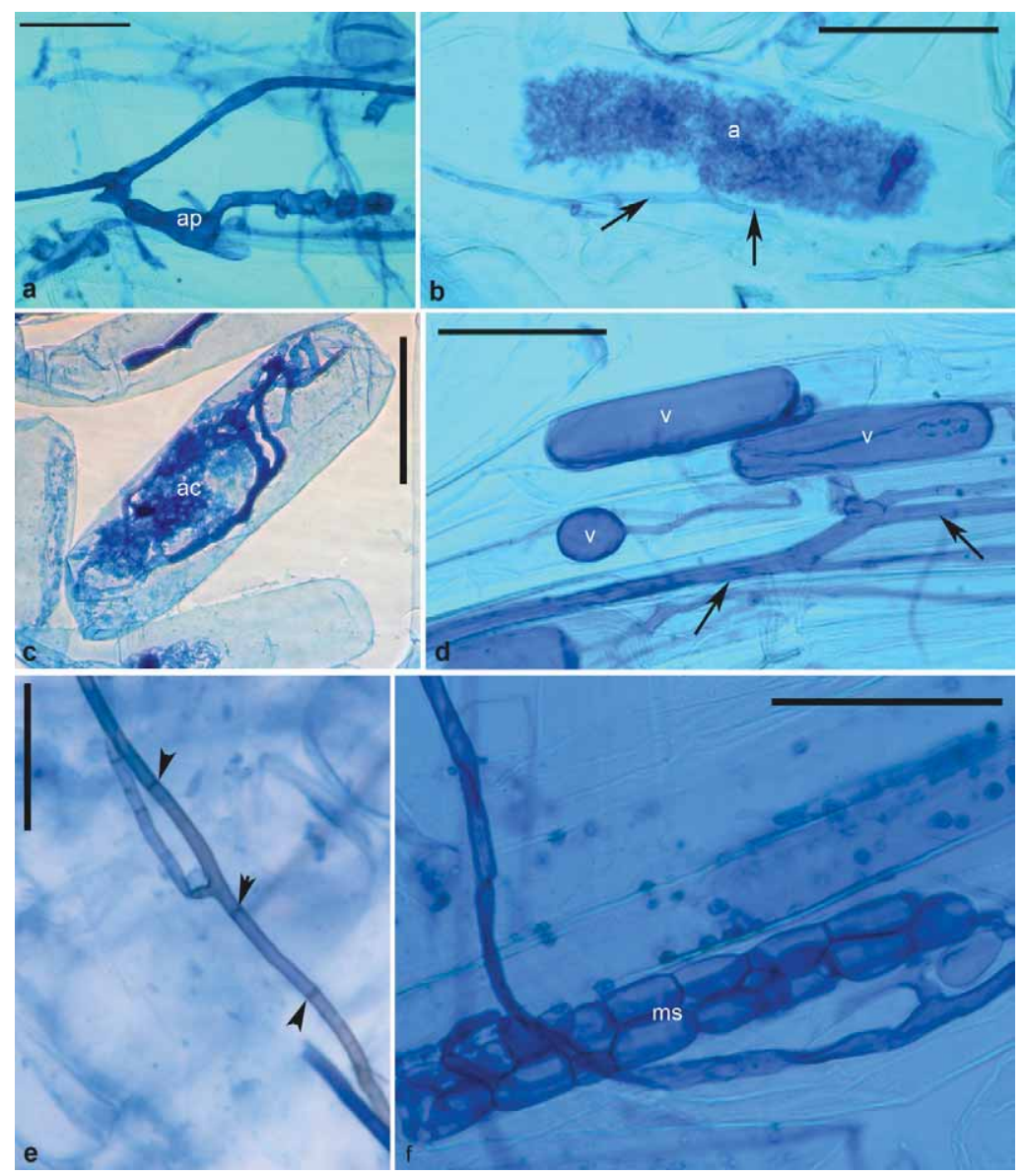

Fig. 1. Arbuscular mycorrhizal (AM) and dark septate endophyte (DSE) fungal colonization in the shallot. a - Appressorium (ap) of AMF on the root surface; $\mathbf{b}$ - Arbuscule (a) and intracellular hyphae (arrows) in root cell; c - Arbusculate coil (ac) within a root cell; d - Vesicles (v) and intercellular hyphae; $\mathbf{e}$-Septation (arrow heads) in DSE hyphae; $\mathbf{f}$-Microsclerotia (ms) of DSE in cortical cell. Scale bars $=50 \mu \mathrm{m}$. 
Tab. 2. Extent of arbuscular mycorrhizal (AM) and dark septate endophyte (DSE) fungal association in rhizosphere soils of shallot onion.

\begin{tabular}{|c|c|c|c|c|c|c|c|c|c|c|}
\hline \multirow[t]{3}{*}{ Fields } & \multicolumn{6}{|c|}{$\mathrm{AM}$} & \multirow{2}{*}{\multicolumn{4}{|c|}{$\frac{\text { DSE }}{\text { Colonization }(\%)}$}} \\
\hline & \multicolumn{4}{|c|}{ Colonization (\%) } & \multirow{2}{*}{$\begin{array}{l}\text { Spore number } \\
\left(100 \mathrm{~g}^{-1}\right)\end{array}$} & \multirow{2}{*}{$\begin{array}{l}\text { AM fungal } \\
\text { species }\end{array}$} & & & & \\
\hline & RLH/RLHC & RLA/RLAC & RLV & RLTC & & & RLDH & RLMO & RLMI & RLDTC \\
\hline $\mathrm{F} 1$ & $31.8 \pm 6.2$ & $5.7 \pm 2.2$ & $11.0 \pm 4.3$ & $48.5 \pm 11.7$ & $11.2 \pm 2.5$ & GE, GS1, SC & $13.5 \pm 3.0$ & - & $0.7 \pm 0.5$ & $14.2 \pm 3.3$ \\
\hline $\mathrm{F} 2$ & $20.5 \pm 4.8$ & $2.4 \pm 0.2$ & $2.7 \pm 1.6$ & $25.6 \pm 6.1$ & $14.3 \pm 0.9$ & GS, GA, SC & $33.8 \pm 4.7$ & - & $1.5 \pm 0.8$ & $35.3 \pm 5.0$ \\
\hline F3 & $37.0 \pm 5.2$ & $10.1 \pm 2.2$ & $0.2 \pm 0.1$ & $47.3 \pm 6.6$ & $8.9 \pm 2.6$ & GA, GS1 & $14.1 \pm 4.9$ & - & $0.2 \pm 0.1$ & $14.3 \pm 5.0$ \\
\hline F4 & $37.1 \pm 2.5$ & $7.4 \pm 2.7$ & $1.0 \pm 0.8$ & $45.5 \pm 4.6$ & $10.3 \pm 1.6$ & GE, GA & $12.4 \pm 3.4$ & $0.4 \pm 0.5$ & $0.7 \pm 0.4$ & $13.5 \pm 4.0$ \\
\hline F5 & $15.7 \pm 3.2$ & $3.9 \pm 0.7$ & $1.1 \pm 0.7$ & $20.7 \pm 3.7$ & $8.6 \pm 1.4$ & GE, GA, SC & $3.8 \pm 1.4$ & $1.4 \pm 1.0$ & $0.2 \pm 0.1$ & $5.4 \pm 2.4$ \\
\hline F6 & $31.2 \pm 4.2$ & $15.2 \pm 3.6$ & $0.4 \pm 0.3$ & $46.8 \pm 6.3$ & $16.7 \pm 1.6$ & $\mathrm{GS}, \mathrm{GV}, \mathrm{SC}$ & $4.3 \pm 0.9$ & $0.1 \pm 0.1$ & $0.1 \pm 0.1$ & $4.5 \pm 0.9$ \\
\hline F7 & $34.8 \pm 3.0$ & $9.5 \pm 3.3$ & $1.7 \pm 1.2$ & $46.0 \pm 4.9$ & $15.3 \pm 2.2$ & GV, GE, SC & $14.4 \pm 3.2$ & $0.8 \pm 0.6$ & $1.3 \pm 0.5$ & $16.5 \pm 3.1$ \\
\hline F8 & $34.5 \pm 4.5$ & $18.4 \pm 3.7$ & $0.2 \pm 0.1$ & $53.1 \pm 4.9$ & $17.1 \pm 2.8$ & GA, SC & $4.5 \pm 0.7$ & $0.3 \pm 0.2$ & $0.9 \pm 0.3$ & $5.7 \pm 1.3$ \\
\hline F9 & $35.1 \pm 6.5$ & $16.7 \pm 5.2$ & $0.3 \pm 0.1$ & $52.1 \pm 10.8$ & $15.1 \pm 0.8$ & GS1, SC & $3.1 \pm 1.0$ & $1.7 \pm 1.2$ & $0.3 \pm 0.1$ & $5.1 \pm 1.9$ \\
\hline F10 & $38.1 \pm 4.3$ & $12.9 \pm 4.0$ & $0.1 \pm 0.1$ & $51.1 \pm 6.6$ & $13.9 \pm 2.2$ & GE, SC & $6.2 \pm 2.9$ & $0.9 \pm 0.5$ & $0.2 \pm 0.1$ & $7.3 \pm 3.1$ \\
\hline F11 & $35.9 \pm 4.6$ & $16.3 \pm 5.0$ & - & $52.2 \pm 8.2$ & $8.9 \pm 2.3$ & GE, GS1 & $4.7 \pm 0.6$ & $1.0 \pm 0.9$ & - & $5.7 \pm 1.2$ \\
\hline F12 & $33.5 \pm 3.4$ & $18.1 \pm 4.5$ & $0.5 \pm 0.4$ & $52.1 \pm 5.5$ & $11.9 \pm 2.8$ & GA, GS, SC & $4.4 \pm 1.4$ & $0.4 \pm 0.5$ & - & $4.8 \pm 1.6$ \\
\hline F13 & $38.7 \pm 2.8$ & $19.1 \pm 3.0$ & $0.1 \pm 0.1$ & $57.9 \pm 5.6$ & $8.8 \pm 2.1$ & GS1 & $3.5 \pm 1.3$ & $1.9 \pm 1.0$ & $0.4 \pm 0.6$ & $5.8 \pm 1.6$ \\
\hline F14 & $30.6 \pm 5.7$ & $14.9 \pm 3.2$ & $0.6 \pm 0.3$ & $46.1 \pm 8.5$ & $7.4 \pm 1.5$ & GE, GS1 & $3.8 \pm 1.2$ & $0.4 \pm 0.4$ & - & $4.2 \pm 1.6$ \\
\hline F15 & $30.3 \pm 1.8$ & $15.1 \pm 2.3$ & $0.1 \pm 0.1$ & $45.5 \pm 3.5$ & $8.1 \pm 1.3$ & GS1 & $3.5 \pm 1.2$ & - & $0.1 \pm 0.1$ & $3.6 \pm 1.2$ \\
\hline F16 & $28.0 \pm 3.5$ & $21.6 \pm 4.2$ & $0.2 \pm 0.1$ & $49.8 \pm 7.8$ & $12.6 \pm 2.7$ & $\begin{array}{l}\text { GA, GE, GS, } \\
\text { GS1, SC }\end{array}$ & $21.7 \pm 1.8$ & $0.6 \pm 0.4$ & $0.2 \pm 0.1$ & $22.5 \pm 1.8$ \\
\hline F17 & $41.1 \pm 2.0$ & $22.8 \pm 3.7$ & $2.9 \pm 1.4$ & $66.8 \pm 3.4$ & $12.8 \pm 3.2$ & $\begin{array}{l}\text { GE, GS, } \\
\text { GV,SC }\end{array}$ & $18.1 \pm 1.7$ & - & $0.4 \pm 0.3$ & $18.5 \pm 1.8$ \\
\hline F18 & $38.8 \pm 1.9$ & $24.5 \pm 1.9$ & $1.4 \pm 1.0$ & $64.7 \pm 2.1$ & $13.3 \pm 3.3$ & GA, GS, SC & $19.7 \pm 1.1$ & $0.2 \pm 0.2$ & $0.5 \pm 0.4$ & $20.4 \pm 0.7$ \\
\hline F19 & $42.1 \pm 1.1$ & $23.9 \pm 3.8$ & $1.3 \pm 0.7$ & $67.3 \pm 4.2$ & $3.5 \pm 0.7$ & GE, SC & $19.5 \pm 3.1$ & $0.8 \pm 0.6$ & $0.2 \pm 0.1$ & $20.5 \pm 3.8$ \\
\hline F20 & $35.1 \pm 3.6$ & $8.5 \pm 1.7$ & - & $43.6 \pm 5.2$ & $3.7 \pm 1.0$ & GE, GS, SC & $13.0 \pm 2.1$ & $1.1 \pm 0.7$ & $0.3 \pm 0.2$ & $14.4 \pm 2.3$ \\
\hline Plants $\left(\mathrm{P}_{4,200}\right)$ & $1.6 * *$ & $2.4 * *$ & $5.9 * *$ & $1.8^{* *}$ & $<1 \mathrm{~ns}$ & & $<1 \mathrm{~ns}$ & $3.7 * *$ & $2.6^{*}$ & $<1 \mathrm{~ns}$ \\
\hline Fields $\left(\mathrm{F}_{19,200}\right)$ & $12.0 * *$ & $17.5 * *$ & $20.9 * *$ & $17.0 * *$ & $3.71 * *$ & & $47.8 * *$ & $3.0 * *$ & $1.7 *$ & $34.4 * *$ \\
\hline $\mathrm{P} \times \mathrm{F}\left(\mathrm{F}_{99,200}\right)$ & $2.81 * *$ & $2.7 * *$ & $3.0^{* * *}$ & $13.7 * *$ & $<1 \mathrm{~ns}$ & & $2.5 * *$ & $1.6^{* *}$ & $<1 \mathrm{~ns}$ & $2.2 * *$ \\
\hline
\end{tabular}

RLH/RLHC - root length with hyphae or hyphal coils, RLA/RLAC - root length with arbuscles or arbusculate coils, RLV - root length with vesicles, RLTC - total colonization, RLDH - root length with dark septate hyphae, RLMO - root length with moniliform hyphae, RLMI - root length with microsclerotia, RLDTC - dark septate endophyte total colonization, GS1 - Glomus species 1, GA - Glomus aggregatum, GE - Glomus etunicatum, GS - Glomus sinuosum, GV - Glomus viscosum, SC - Scutellospora calospora, 
Priyadharsini P., PANdey R. R., Muthukumar T.

\section{Extent of AMF colonization}

The extent of AMF colonization and the root length with different AMF structures varied significantly among roots collected from various fields (Tab. 2). The percentage of total root length with AMF colonization (\%RLTC) ranged from 20.7 (F5) to 67.3 (F19). Total AMF colonization and the percentage of root length with AMF structures significantly varied among plants collected from a field and from different fields. The ranges of percentage root length with AMF hyphae/ hyphal coils (\%RLH/ RLHC), arbuscules/ arbusculate coils (\%RLA/ RLAC) and vesicles (\%RLV) were 15.7 (F5) to 42.1 (F19), 2.4 (F2) to 24.5 (F18) and 0.1 (F10, F13, F15) to 11.0 (F1) respectively. Compared with average \%RLH/ RLHC (33.5) and \%RLA/ RLAC (14.3), \%RLV was lower (1.3) and vesicles were not observed in onion roots collected from two fields (F11 and F20). Correlation analysis indicated \% RLH/ RLHC, \%RLA/ RLAC and \%RLTC to be significantly and positively correlated to soil pH and Fe. Similarly, a significant positive correlation also existed between \%RLA/ RLAC and soil Mn. In contrast \%RLV was significantly and negatively correlated to soil Zn content.

\section{Extent of DSE colonization}

Significant variation in percentage of root length with DSE colonization (\%RLDTC) was evident among onion roots collected from different fields and ranged between 3.6 (F15) and 35.3 (F2). The percentage of root length with dark septate hyphae (\%RLDH) ranged from 3.1 (F9) to 33.8 (F2) and varied significantly among fields. Likewise, the percentage of root length with moniliform hyphae (\%RLMO) and microsclerotia (\%RLMI) varied significantly both within and among fields ranged from 0.1 (F6) to 1.9 (F13) and 0.1 (F6, F15)to $1.5(\mathrm{~F} 2)$ respectively.

The \%RLMI was significantly and negatively correlated with soil P. Similarly \%RLDH and \%RLDTC was also significantly and negatively correlated to soil $\mathrm{Zn}$ and $\mathrm{Cu}$. In contrast, \%RLMO was significantly and positively correlated to Zn. Neither \%RLDTC nor root length with DSE structures were correlated to \%RLTC or AMF structures (Tab. 3).

\section{Distribution of AMF spores}

Total spore counts significantly varied among the fields and ranged from $4(\mathrm{~F} 19,20)$ to 17 (F18) spores per $100 \mathrm{~g}$ soil. Correlation analysis indicated the lack of correlation between $\%$ RLTC and spore numbers $(\mathrm{r}=-0.022 ; \mathrm{p}>0.05)$. However, spore numbers were significantly and positively correlated to soil $\mathrm{K}$ and negatively to soil $\mathrm{N}$ (Tab. 3).

A total of six AMF morphotypes of two genera were distinguished on the basis of spore morphology; they included Glomus species 1, Glomus aggregatum N. C. Schenck et G. S. Sm., Glomus etunicatum W. N. Becker et Gerd., Glomus sinuosum (Gerd. et B.K. Bakshi) Almeida et Schenck, Glomus viscosum T. H. Nicolson and Scutellospora calospora (T. H. Nicolson et Gerd.) C. Walker et F.E. Sanders, one of which could not be identified at species level (Fig. 2). Scutellospora calospora (70\%) was the most frequent AMF morphotype associated with onion (Figs. 3, 4). 
Tab. 3. Pearson's correlation coefficients between various arbuscular mycorrhizal fungi (AMF), dark septate fungal endophyte (DSE) and soil variables (SV).

\begin{tabular}{|c|c|c|c|c|c|c|c|c|c|}
\hline \multirow[t]{2}{*}{ SV } & \multicolumn{5}{|c|}{ AMF } & \multicolumn{4}{|c|}{ DSE } \\
\hline & $\begin{array}{r}\text { RLH/ } \\
\text { RLHC }\end{array}$ & $\begin{array}{l}\text { RLA/ } \\
\text { RLAC }\end{array}$ & RLV & RLTC & SP & RLDH & RLMO & RLMI & RLDTC \\
\hline $\mathrm{pH}$ & $0.519 *$ & $0.477 *$ & 0.306 & $0.638 * *$ & -0.414 & 0.252 & -0.118 & -0.041 & 0.241 \\
\hline EC & 0.085 & 0.095 & -0.166 & 0.068 & 0.204 & -0.256 & 0.185 & -0.212 & -0.252 \\
\hline $\mathrm{N}$ & 0.246 & 0.328 & -0.057 & 0.318 & $-0.466^{*}$ & 0.230 & 0.087 & -0.283 & 0.224 \\
\hline P & -0.161 & 0.374 & -0.203 & 0.083 & -0.023 & 0.050 & -0.082 & $-0.446^{*}$ & 0.026 \\
\hline K & 0.442 & 0.258 & 0.041 & 0.410 & $-0.608 * *$ & 0.146 & 0.129 & -0.173 & 0.148 \\
\hline $\mathrm{Fe}$ & $0.488^{*}$ & $0.498^{*}$ & -0.064 & $0.553^{*}$ & -0.242 & 0.426 & -0.048 & 0.091 & 0.425 \\
\hline $\mathrm{Mn}$ & 0.099 & $0.525^{*}$ & -0.403 & 0.275 & 0.014 & -0.085 & 0.264 & -0.277 & -0.080 \\
\hline $\mathrm{Zn}$ & -0.074 & 0.072 & $-0.487^{*}$ & -0.105 & 0.029 & $-0.577 * *$ & $0.459 *$ & -0.118 & $-0.551 *$ \\
\hline $\mathrm{Cu}$ & -0.184 & -0.341 & 0.016 & -0.299 & 0.267 & $-0.507 *$ & 0.055 & 0.079 & $-0.500 *$ \\
\hline
\end{tabular}

Significance at $1 \%$ level (**) and 5\% level (*)

RLH/ RLHC - root length with hyphae or hyphal coils

RLA/RLAC - root length with arbuscles or arbusculate coils

RLV - root length with vesicles

RLTC - total colonization

$\mathrm{SP}$ - spore number

RLDH - root length with dark septate hyphae

RLMO - root length with moniliform hyphae

RLMI - root length with microsclerotia

RLDTC - dark septate endophyte total colonization

\section{Discussion}

Taxa in Allium are known to form typical Arum-type morphologies (SMITH and SMITH 1997, DiCKSON et al. 2007) and this is the first report of the intermediate-type AMF in the genus Allium and family Aliaceae. The intermediate-type AMF morphology of the shallot is intermediate to the I3 and I4 subtypes described by DiCKSON (2004). Although the exact factors influencing AMF morphology are not known, it has been suggested that both host root structure and AMF fungal genotypes influence AMF morphology (Dickson et al. 2007). Shallot roots in conventional agricultural fields had AMF colonization levels within the ranges of those reported in other studies (MUTHUKUMAR and TAMILSELVI 2010, AliASGHARZAD et al. 2009, Goussous and MoHAMmAd 2009, JAime et al. 2008). However, the average AMF colonization (49.12\%) is lower than those reported for onions under conventional cultivation in Fevoland (91\%) and Zeeland (72\%) of the Netherlands (GALVÁN et al. 2009). Similarly, the \%RLA/RLAC in the present study was three- to five-fold lower than reported for conventional onion cultivation in the Netherlands (GALVÁN et al. 2009). Generally, low levels of AMF colonization in conventionally managed soils were explained by high soil $\mathrm{P}$ concentrations. This was not clearly the case of the onion fields in the present study as we found those AMF colonization parameters were not correlated to the concentrations of $\mathrm{P}$ in the soil. Our observations on the lack of correlation between soil $\mathrm{P}$ and AMF variables suggests that the soil $\mathrm{P}$ concentrations in the field soils were well below the threshold levels that could influence AMF. The average soil P in the present study $\left(6.4 \mathrm{mg} \mathrm{kg}^{-1}\right)$ was almost seven fold lower than P concentrations reported for Dutch soils used for con- 

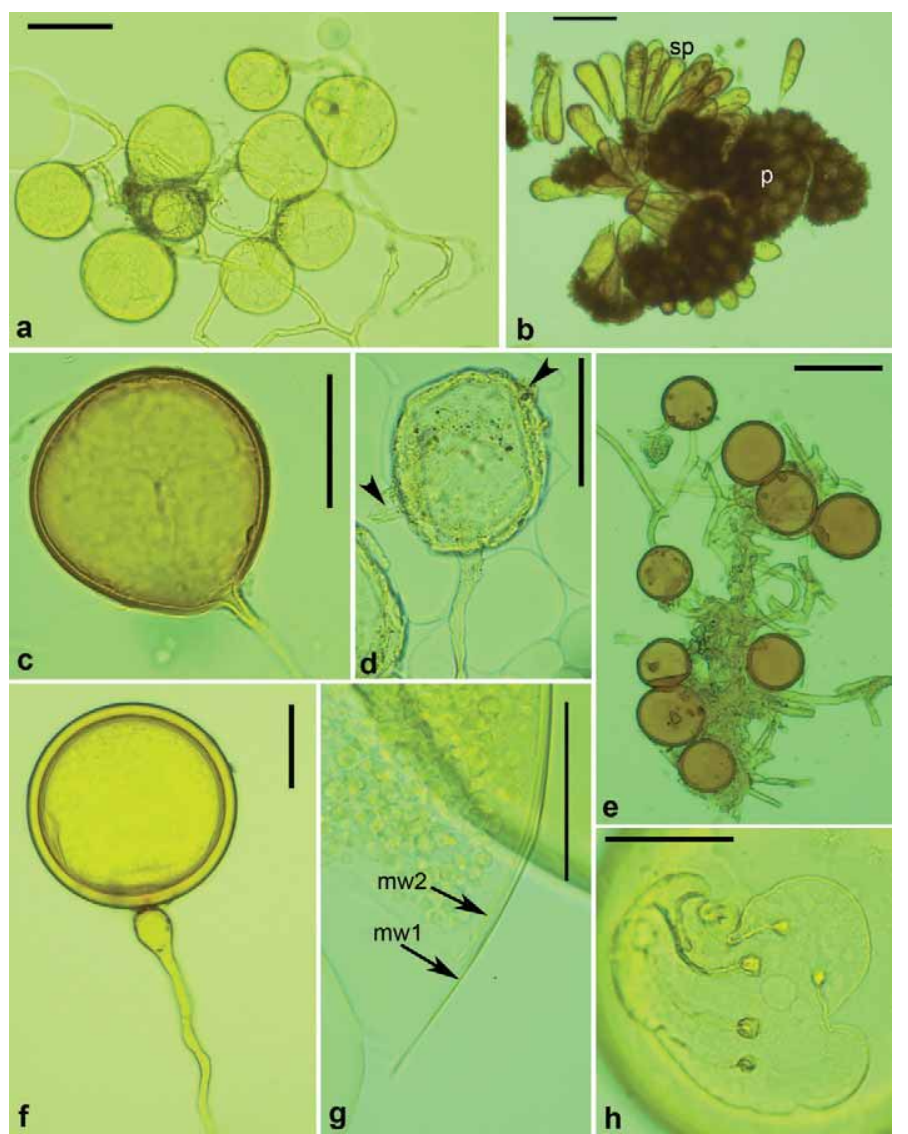

Fig. 2. Arbuscular mycorrhizal spores isolated from the soils of shallot onion. a-Glomus aggregatum; $\mathbf{b}$ - Fractured sporocarp of Glomus sinuosum; p, peridium; sp, spores; c - Glomus etunicatum; $\mathbf{d}$ - Glomus viscosum with attached soil particles (arrowheads); $\mathbf{e}-$ Glomus sp.1; f - Scutellospora calospora; $\mathbf{g}$ - Membranous walls (mw1, mw2) of S. calospora; $\mathbf{h}$ - Germination shield of $S$. calospora. Scale bars: a, b, e, f = $100 \mu \mathrm{m} ; \mathrm{c}, \mathrm{d}, \mathrm{g}, \mathrm{h}=50 \mu \mathrm{m}$.

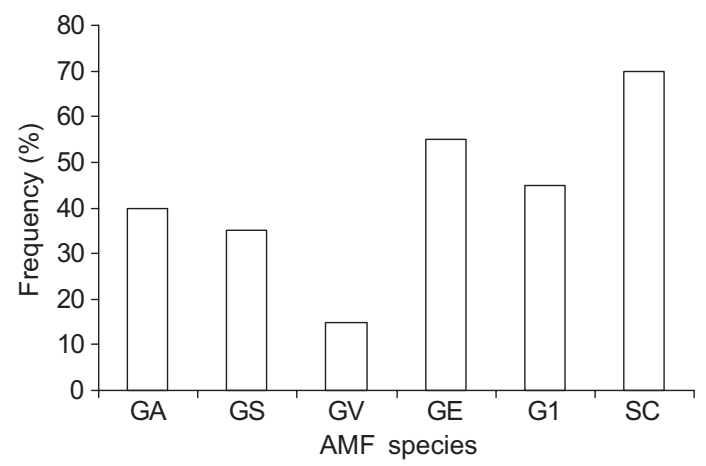

Fig. 3. Arbuscular mycorrhizal fungal (AMF) frequency in the soils used for shallot cultivation. For AMF species abbreviations see Tab. 2. 


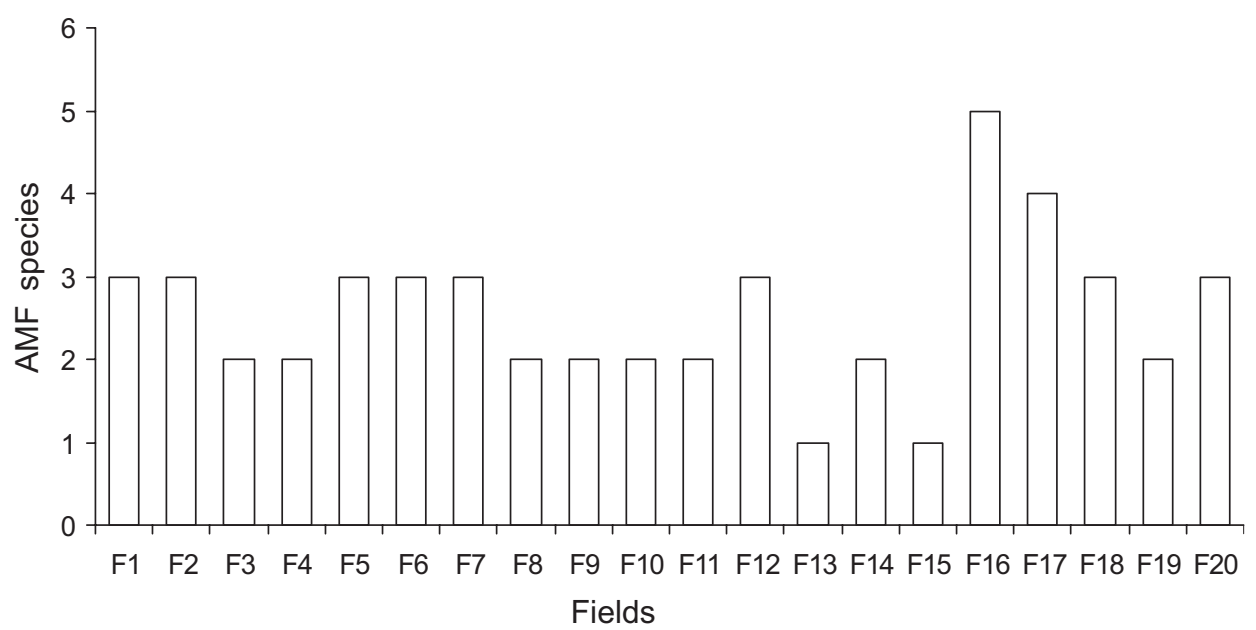

Fig. 4. Arbuscular mycorrhizal fungal (AMF) diversity in shallot soils.

ventional cultivation of onions (GALVÁn et al. 2009). The lack of correlation between soil P and mycorrhizal parameters agreed with the observation of GALVÁN et al. (2009), but contrasted with studies where an inverse correlation had been reported between these variables (ANANTHAKRISHNAN et al. 2004, LinGFEI et al. 2005, KHANAM et al. 2006, VALSALAKUMAR et al. 2007, Das and KAYANG 2010b).

Soil $\mathrm{pH}$ has a great relevance for plant growth as it influences nutrient mobilization as well as availability (MARSCHNER 1995). Many studies reporting the influence of soil factors on AMF colonization have failed to find any relationship between soil $\mathrm{pH}$ and colonization (ZahKa et al. 1995, Khade and Rodrigues 2008, Valsalakumar et al. 2007, Oliveira and Oliveira 2010, KHANAM et al. 2006). In the present study $\mathrm{pH}$ of the soil was positively correlated to all AMF colonization parameters except \%RLV. LINGFEI et al. (2005) found results similar to ours, where soil $\mathrm{pH}$ was found to be correlated with the extent of hyphal and arbuscular colonization in grasses. Colonization and extraradial mycelium formation by AMF are known to be altered by soil pH (VAn AARLE et al. 2002). COUGHLAn et al. (2000) inferred that the tendency for colonization levels to increase with $\mathrm{pH}$ was due to the stimulation of the additional AMF taxa and/or a greater ability of the taxa present to colonize host roots. However, the positive influence of $\mathrm{pH}$ on AMF colonization contradicts the observations of WANG et al. (2008) and FORTIN et al. (2002) where increasing soil pH had detrimental effects on AMF spore germination and mycorrhization.

Though less studied than those of other soil nutrients, Fe deficiencies at high soil $\mathrm{pH}$ are known to suppress colonization by AMF (WANG et al. 2008). The positive correlation between soil Fe and AMF variables indicate that Fe could stimulate colonization by AMF. A similar correlation has been reported in Paullinia cupana during the rainy season by Oliveira and Oliveira (2010). Michelini et al. (1993) indicated that Fe interacts with other soil nutrients like $\mathrm{Ca}, \mathrm{Mn}$ or $\mathrm{P}$ to influence AMF colonization and can greatly be influenced by soil $\mathrm{pH}$. In the present study, soil Fe was also significantly and positively correlated to soil $\mathrm{pH}(\mathrm{r}=0.565 ; \mathrm{p}<0.01 ; \mathrm{n}=20)$. Contrarily, to the observations of AUDET and CHAREST (2006), Zn and \%RLV had an inverse correlation in the present study. The nega- 
tive effect of soil $\mathrm{Zn}$ can be due to the directly suppressive effect of $\mathrm{Zn}$ on AMF propagules or the indirect effect on host roots.

The average AMF spore number (11 spores per $100 \mathrm{~g}$ soil) recorded in the present study is lower than the range of 54-3920 spores per 100g soil reported for tropical soils (VALSALAKUMAR et al. 2007, KHANAM et al. 2006, KHADE and Rodrigues 2008, OliveIRA and OLIVEIRA 2010, ANANTHAKRISHNAN et al. 2004, DAS and KAYANG 2010b). Major portions of AMF spores occurring in field soils are either dead or spore cases (MUTHUKUMAR and UDAIYAN 1999) and the spore numbers presented in this study are only for intact spores. The lack of correlation between \%RLTC and spore numbers agrees with the observations of VALSALAKUMAR et al. (2007) in Phaseolus aureus, ZAHKA et al. (1995) in Acer saccharum, KHALIL and LOYNACHAN (1994) in Glycine max and SASAI (1992) in cultivated plants of Miyagi prefecture, Japan. Such a lack of correlation between AMF colonization and spore numbers indicate that the factors influencing these variables are totally different. In this study AMF spore numbers were negatively correlated to soil $\mathrm{N}$ and $\mathrm{K}$. This contradicts the suggestions that soil K could stimulate the production of AMF spores (OLIVEIRA and OLIVEIRA 2010). This influence of soil $\mathrm{N}$ and $\mathrm{K}$ on AMF spore numbers can be attributed to their influence on soil $\mathrm{pH}$ as soil $\mathrm{N}(\mathrm{r}=0.463)$ and soil $\mathrm{K}(\mathrm{r}=0.464)$ were correlated $(\mathrm{p}<0.05)$ to soil $\mathrm{pH}$.

A total of one to five AMF taxa were detected in conventionally cultivated onion field soil. This is lower than the 8 to 20 species that are usually reported for arable lands (LAND and SCHÖNBECK 1991, DoudS and MilLnER 1999, FiTTER, 2001, JANSA et al. 2002). However, the AMF diversity in the present study is within ranges observed for a site by ANANTHAKRISHNAN et al. (2004) and SJÖBERG et al. (2004). VALSALAKUMAR et al. (2007) also reported very low AMF diversities of one to three taxa for the 21 sampling locations under Phaseolus aureus cultivation in Tamil Nadu and Karnataka of South India. The presence of low AMF diversity could be due to the selection pressure imposed by cultivation practices resulting in the dominance of fast growing species (OEHL et al. 2004) and species that are able to tolerate stresses like tillage, fertilizer and biocide applications (GosLING et al. 2006, GALVÁN et al. 2009).

DSE colonization had been reported in roots of several crop species and in roots also colonized by AMF (JumPPONEN and TRAPPE 1998, MuthuKuMAR and TAMILSELVi 2010). In this study, the root systems of all shallot onions examined were commonly colonized by both DSE and AMF. DSE colonization has been reported in onions from both temperate and tropical agroecosystems (JumPPONEN and TRAPPE 1998, MUTHUKUMAR and TAMILSELVI 2010). It is interesting to note that the extent of \%RLDTC was always lower (except F2) than \%RLTC. Further, the lack of correlation between root lengths colonized by AMF and DSE clearly suggest that these two fungal types do not compete for resources within roots. However, the results of a recent study by SCERVINO et al. (2009) show that DSE could modify mycorrhizal status of plants.

The correlation analysis showed that soil $\mathrm{Zn}$ and $\mathrm{Cu}$ influenced DSE colonization and structures, which is in line with the observation of CHRISTIE and KILPATRICK (1992). In contrast, LINGFEI et al. (2005) found no significant correlations between DSE colonization and soil factors. The response of DSE to soil nutrients appears to vary with soil conditions. For example, CHRISTIE and KILPATRICK (1992) found an inverse correlation between $\mathrm{Cu}$ and $\mathrm{Zn}$ to DSE colonization in soil amended cow slurry but not in soil amended with pig slurry. At present, the ecology of DSE association in crop plants has not been documented. As grow- 
ing evidence suggests that DSE may influence plant growth in a way similar to AMF (WU et al. 2010, Wu and GuO 2008, FuMIAKI and KAZUHIKO 2007), an understanding of the factors influencing their associations and function would enable their possible exploitation in agriculture.

\section{References}

Аввотт, L. K., GAZEY, C., 1994: An ecological view of the formation of VA mycorrhizas. Plant and Soil 159, 69-78.

Addy, H. D., Piercey, M. M., Currah, R. S., 2005: Macrofungal endophytes in roots. Canadian Journal of Botany 83, 1-13.

Aliasgharzad, N., Bolandnazar, S. A., Neyshabouri, M. R., Chaparzadeh, N., 2009: Impact of soil sterilization and irrigation intervals on $\mathrm{P}$ and $\mathrm{K}$ acquisition by mycorrhizal onion (Allium cepa). Biologia 64, 512-515.

AnANthakrishnan, G., Ravikumar, R., Girija, S., GANAPATHi, A., 2004: Selection of efficient arbuscular mycorrhizal fungi in the rhizosphere of cashew and their application in cashew nursery. Scientia Horticulturae 100, 369-375.

Anonymous, 1986: Pest control in tropical onions. Tropical Development and Research Institute, London.

Audet, P., ChARest, C., 2006: Effects of AM colonization on wild tobacco plants grown in zinc contaminated soil. Mycorrhiza 16, 277-283.

Balestrini, R., Magurno, F., Walker, C., Lumini, E., Bianciotto, V., 2010: Cohorts of arbuscular mycorrhizal fungi (AMF) in Vitis vinifera, a typical Mediterranean fruit crop. Environmental Microbiology Reports 12, 593-604.

Bever, J. D., Morton, J. B., Antonovics, J., Schultz, P. A., 1996: Host-dependent sporulation and species diversity of arbuscular mycorrhizal fungi in a mown grassland. Journal of Ecology 84, 71-82.

Bolandnazar, S., Aliasgharzad, N., Neishabury, M. R., Chaparzadeh, N., 2007: Mycorrhizal colonization improves onion (Allium cepa L.) yield and water use efficiency under water deficit condition. Scientia Horticulturae 114, 11-15.

Bosch-Serra, A. D., Currah, L., 2002: Agronomy of onions. In: Rabinowitch, H. D., Currah, L. (eds.), Allium crop science: recent advances, 187-197. CAB International, Wallingford.

BowELS, J. E., 1992: Engineering properties of soils and their measurement. McGraw-Hill International Edition, Civil Engineering Series, McGraw-Hill, Singapore.

Christie, P., Kilpatrick, D. J., 1992: Vesicular-arbuscular mycorrhiza infection in cut grassland following long-term slurry application. Soil Biology and Biochemistry 24, 325-330.

Coughlan, A. P., Dalpé, Y., Lapointe, L., Piché, Y., 2000: Soil pH-induced changes in root colonization, diversity, and reproduction of symbiotic arbuscular mycorrhizal fungi from healthy and declining maple forests. Canadian Journal of Forest Research 30, 1543-1554.

DAS, P., KAYAng, H., 2010a: Mycorrhizal colonization and distribution of arbuscular mycorrhizal fungi associated with Michelia champaca L. under plantation system in northeast India. Journal of Forest Research 21, 137-142. 
DAs, P., KaYAng, H., 2010b: Association of dark septate endophytes and arbuscular mycorrhizal fungi in potato under field conditions in the northeast region of India. Mycology $1,171-178$.

Deressa, T. G., Schenk, M. K., 2008: Contribution of roots and hyphae to phosphorus uptake of mycorrhizal onion (Allium cepa L.) - a mechanistic modeling approach. Journal of Plant Nutrition and Soil Science 171, 810-820.

Dickson, S., 2004: The Arum-Paris continuum of mycorrhizal symbiosis. New Phytologist 163, 187-200.

Dickson, S., Smith, F. A., Smith, S. E., 2007: Structural differences in arbuscular mycorrhizal symbiosis. More than 100 years after Gallaud, where next? Mycorrhiza 17, 375-393.

Douds, D. D., Millner, P. D., 1999: Biodiversity of arbuscular mycorrhizal fungi in agroecosystems. Agriculture Ecosystem and Environment 74, 77-93.

FITTER, A. H., 2001: Specificity, links and networks in the control of diversity in plant and microbial communities. In: Press, M. C., Huntly, N. J., Levin, S. (eds.), Ecology: achievement and challenge. Proceedings 41 Symposium of the British Ecological Society, 95-114. Orlando, FL, USA.

Fortin, J. A., Becard, G., Declerck, S., Dalpe, Y., St-Arnaud, M., Coughlan, A. P., Piche, Y., 2002: Arbuscular mycorrhiza on root-organ cultures. Canadian Journal of Botany 80, 1-20.

FumiaKi, U., KAZUHIKo, N., 2007: A mutualistic symbiosis between a dark septate endophytic fungus, Heteroconium chaetospira, and a nonmycorrhizal plant, Chinese cabbage. Mycologia 99, 175-184.

Galván, G. A., Kuyper, T. W., Burger, K., Keizer, L. C. P., Hoekstra, R. F., Kik, C., Scholten, O. E., 2011: Genetic analysis of the interaction between Allium species and arbuscular mycorrhizal fungi. Theoretical and Applied Genetics 122, 947-960.

Galván, G. A., PArádi, I., Burger, K., BaAr, J., Kuyper, T. W., Scholten, O. E., Kik, C., 2009: Molecular diversity of arbuscular mycorrhizal fungi in onion roots from organic and conventional farming systems in the Netherlands. Mycorrhiza 19, 317-328.

Gianinazzi, S., Gollotte, A., Binet, M. N., Van Tuinen, D., Redecker, D., Wipf, D., 2010: Agroecology: the key role of arbuscular mycorrhizas in ecosystem services. Mycorrhiza 20, 519-530.

Gosling, P., Hodge, A., Goodlass, G., Bending, G. D., 2006: Arbuscular mycorrhizal fungi and organic farming. Agriculture Ecosystem and Environment 113, 17-35.

Goussous, S. J., Mohammad, M. J., 2009: Comparative effect of two arbuscular mycorrhizae and $\mathrm{N}$ and $\mathrm{P}$ fertilizers on growth and nutrient uptake of onions. International Journal of Agriculture and Biology 11: 463-467.

HART, M. M., READER, R. J., 2002: Taxonomic basis for variation in the colonization strategy of arbuscular mycorrhizal fungi. New Phytologist 153, 335-344.

HART, M. M., REAdER, R. J., KLIRONOMOS, J. N., 2001: Life-history strategies of arbuscular mycorrhizal fungi in relation to their successional dynamics. Mycologia 93, 11861194.

Husband, R., Herre, E. A., Turner, S. L., Gallery, R., Young, J. P. W., 2002: Molecular diversity of arbuscular mycorrhizal fungi and patterns of host association over time and space in a tropical forest. Molecular Ecology 11, 2669-2678. 
JACKSON, M. L., 1971: Soil chemical analysis. Prentice Hall, New Delhi, India.

Jaime, M. D. L. A., Hsiang, T., McDOnAlD, M. R., 2008: Effects of Glomus intraradices and onion cultivar on Allium white rot development in organic soils in Ontario. Canadian Journal of Plant Pathology 30, 543-553.

Jansa, J., Mozafar, A., Anken, T., Ruh, R., SAnders, I. R., Frossard, E., 2002: Diversity and structure of AMF communities as affected by tillage in a temperate soil. Mycorrhiza 12, 225-234.

JuMPPONEN, A. 2001: Dark septate endophytes-are they mycorrhizal? Mycorrhiza 11, 207-211.

Jumpronen, A., Trappe, J. M., 1998: Dark septate endophytes: a review of facultative biotropic root-colonizing fungi. New Phytologist 140, 295-310.

KHADE, S. W., RodRigues, B. F., 2008: Ecology of arbuscular mycorrhizal fungi associated with Carrica papaya L. in agro-based ecosystem of Goa, India. Tropical and Subtropical Agroecosystems 8, 265-278.

KHALIL, S., LOYNACHAN, T. E., 1994: Soil drainage and distribution of VAM fungi in two toposequences. Soil Biology and Biochemistry 26, 929-934.

Khanam, D., Mridha, M. A. U., Solaiman, A. R. M., Hossain, T., 2006. Effect of edaphic factors on root colonization and spore population of arbuscular mycorrhizal fungi. Bulletin of the Institute of Tropical Agriculture Kyushu University 29, 97-104.

Koske, R. E., Gemma, J. N., 1989: A modified procedure for staining roots to detect VAmycorrhizas. Mycological Research 92, 486-488.

Koske, R. E., Tessier, B., 1983: A convenient, permanent slide mounting medium. Mycological Society of America News Letter 34, 59.

LAND, S., SCHÖNBECK, F., 1991: Influence of different soil types on abundance and seasonal dynamics of VAM fungi in the arable soils of North Germany. Mycorrhiza 1, 39-44.

LindSAY, W. L., NoRVELl, W. A., 1978: Development of DTPA soil test for zinc, iron, manganese and copper. Soil Science and Plant Analysis 9, 193-202.

LingfeI, L., ANNA, Y., ZHIweI, Z., 2005: Seasonality of arbuscular mycorrhizal symbiosis and dark septate endophytes in a grassland site in southwest China. FEMS Microbiology Ecology 54, 367-373.

MANDYAm, K., JumPPONEN, A., 2005: Seeking the elusive function of the root colonizing dark septate endophytic fungi. Studies in Mycology 53, 173-189.

MAndyam, K., JumpPonen, A., 2008: Seasonal and temporal dynamics of arbuscular mycorrhizal and dark septate endophytic fungi in a tallgrass prairie ecosystem are minimally affected by nitrogen enrichment. Mycorrhiza 18, 145-155.

Marschner, H., 1995: Mineral nutrition of higher plants. Academic Press, London.

McGonigle, T. P., Miller, M. H., Evans, D. G., Fairchild, G. L., Swan, J. A., 1990: A method which gives an objective measure of colonization of roots by vesicular-arbuscular mycorrhizal fungi. New Phytologist 115, 495-501.

Mengel, K., Kirkby, E. A., 2001: Principle of plant nutrition. Kluwer Academic Publishers, Dordsecht.

Michelini, S., Nemec, S., ChinNery, L. E., 1993: Relationships between environmental factors and levels of mycorrhizal infection of citrus on four islands in the Eastern Caribbean. Tropical Agriculture 70, 135-140. 
Muthukumar, T., TAmilselvi, V., 2010: Occurrence and morphology of endorhizal fungi in crop species. Tropical and Subtropical Agroecosystems 12, 593-604.

MuthuKumar, T., UdAIYAN, K., 1999: Spore-in-spore syndrome in vesicular-arbuscular mycorrhizal fungi and its seasonality in a tropical grassland. Nova Hedwigia 68, 339-349.

Oehl, F., Sieverding, E., Mäder, P., Dubois, D., Ineichen, K., Boller, T., Wiemken, A., 2004: Impact of long-term conventional and organic farming on the diversity of arbuscular mycorrhizal fungi. Oecologia 138, 574-583.

Oliveira, A. N., Oliveira, L. A., 2010: Influence of edapho-climatic factors on the sporulation and colonization of arbuscular mycorrhizal fungi in two Amazonian native fruit species. Brazilian Archives of Biology and Technology 53, 653-661.

Plenchette, C., Clermont-Dauphin, C., Meynard, J. M., Fortin, J. A., 2005: Managing arbuscular mycorrhizal fungi in cropping systems. Canadian Journal of Plant Science $85,31-40$.

SANDERS, I. R., FitTER, A. H., 1992: Evidence for differential responses between host-fungus combinations of vesicular-arbuscular mycorrhizas from a grassland. Mycological Research 96, 477-480.

SASAI, K., 1992: Infection of vesicular-arbuscular fungi to plants and spore numbers in cultivated soils in Miyagi Prefecture. Reports of the Miyagi Agricultural College 40, 1-9.

Scervino, J. M., Ponce, M. A., Monica, I. D., Vierheilg, H., Ocampo, J. A., Godeas, A., 2009: Development of arbuscular mycorrhizal fungi in the presence of different patterns of Triflolium repens shoot flavonoids. Journal of Soil Science and Plant Nutrition 9, 102-115.

Schenck, N. C., Perez, Y., 1990: Manual for the identification of VA mycorrhizal fungi. Synergistic Publications, Gainesville, Florida.

Singh, S., Pandey, A., Chaurasia, B., Palni, L. M. S., 2008: Diversity of arbuscular mycorrhizal fungi associated with the rhizosphere of tea growing in 'natural' and 'cultivated' ecosites. Biology and Fertility of Soils 44, 491-500.

Sjöberg, J., Persson, P., Mårtensson, A., Mattsson, L., Adholeya, A., Alström, S., 2004: Occurrence of Glomeromycota spores and some arbuscular mycorrhizal fungal species in arable fields in Sweden. Acta Agriculturae Scandinavia, Section B, Soil and Plant Sciences 54, 202-212.

Sмiтh, F. A., Sмiтн, S. E., 1997: Structural diversity in vesicular-arbuscular mycorrhizal symbiosis. New Phytologist 137, 373-388.

Smith, S. E., ReAd, D. J., 2008: Mycorrhizal symbiosis. Academic Press Inc, San Diego.

SUHARDI, H. A., 1996: Effect of planting date and fungicide applications on the intensity of anthracnose on shallot. Indonesian Journal of Horticulture 6, 172-180.

Valsalakumar, N., RAY, J. G., PotTy, V. P., 2007: Arbuscular mycorrhizal fungi associated with Green gram in Southern India. Argonomy Journal 99, 1260-1264.

VAn AARle, I. M., Olsson, P. A., SöDERSTRÖM, B., 2002: Arbuscular mycorrhizal fungi respond to the substrate $\mathrm{pH}$ of their extraradical mycelium by altered growth and root colonization. New Phytologist 155, 173-182.

Wang, G. M., Stribley, D. P., Tinker, P. B., Walker, C., 1985: Soil pH and vesicular-arbuscular mycorrhizas. In: FitTer, A. H., AtKinson, D., ReAD, D. J., Usher, M. B. (eds.), Ecological interactions in soil, 219-224. Blackwell Scientific Publications, Oxford. 
Wang, Y. Y., Vestberg, M., Walker, C., Hurme, T., Zhang, X., Lindström, K., 2008: Diversity and infectivity of arbuscular mycorrhizal fungi in agricultural soils of the Sichuan Province of mainland China. Mycorrhiza 18, 59-68.

Wu, L., Guo, S., 2008: Interaction between an isolate of dark septate fungi and its host plant Saussurea involucrata. Mycorrhiza 18, 79-85.

Wu, L. Q., Lv, Y. L., Meng, Z. X., Chen, J., GuO, S. X., 2010: The promoting role of an isolate of dark-septate fungus on its host plant Saussurea involucrata Kar. et Kir. Mycorrhiza 20, 127-135.

ZAHKA, G. A., BAGGETT, K. L., Wong, B. L., 1995: Inoculum potential and other VAM fungal parameters in four sugar maple forests with different levels of stand dieback. Forest Ecology and Management 75, 123-134. 